\title{
Distinctive Entrepreneurial Competencies For Competitive Advantage For Entrepreneurs In Rivers State
}

\author{
Wegwu, Macaulay Enyindah \\ Ph.D. Student, Department Of Management Science, University Of Port Harcourt
}

\begin{abstract}
Entrepreneurs believe that they operate in a highly competitive environment. Identifying and focusing on the distinctive competencies of an entrepreneur becomes imperative to achieve dramatic marked advantage over competitors. The purpose of this paper therefore is to x-ray factors most inherent in an individual commitment to becoming an entrepreneur, the choice of goods and services to offer (industry choice and market), entrepreneurial competencies (skills) which involves ability to identify a suitable virgin operational position in existing markets, the mental skill to fashion out new markets, and the talent to quickly exploit the new opportunities. These competencies have become indispensable by dint of stiff competition among firms in industries and the ultimate desire for goods and services from outside national boundaries than home made. The sample size of the study consisted of 80 entrepreneurs drawn from 5 subjectively selected small and medium scale enterprises in Rivers State, namely, servicing, retailing, transportation, manufacturing, and insurance. Data for the study were obtained through the administration of questionnaire and the use of personal interview method. Findings from the study revealed fear of entrepreneurial failures as a result of polarized entrepreneurial educational training on the basic entrepreneurial concepts and their effects on building entrepreneurial confidence. It also revealed the effects of lack of priority attention on adequate infrastructural development as major factors influencing attitudes of individuals to engage in entrepreneurial venture. It was therefore concluded that entrepreneurs should take initiative whenever circumstances demand it to take advantage of external trends that have the potentials of affecting market demands in order to gain competitive advantage over rivalries.
\end{abstract}

Keywords: Distinctive entrepreneurial competencies, entrepreneurial challenges, entrepreneur's competitive intelligence, industry analysis.

\section{Introduction}

The utmost decision to absolutely be a successful entrepreneur involves a very stringent commitment and thus, should be addressed as a major concern, especially in a situation where the startup venture is to be undertaken around a competitive environment. This commitment however can be measured through cognitive mechanisms of self efficacy (Bandura, 1986). It then behoves us to ask questions on the amount of time and efforts many individuals in River State have committed in their bid to becoming successful entrepreneurs, inspite of all the entrepreneurship programs such as poverty alleviation program, skills acquisition, entrepreneurship and empowerment programs initiated by the state government to curb poverty and unemployment alleviation.

With the current level of economic down turn posed by reduction in oil prices around the globe, new and innovation philosophies are springing out to persuade individuals to engage in entrepreneurship, but are still showing unimpressive attitudes. Many who also in recent times are prepared to delve into the business have become psychologically disengaged.

These however, could be accounted for by obvious challenges ranging from knowledge gap currently existing as a result of lack of understanding of individuals who had engaged in entrepreneurship businesses in Rivers State to inconsistent power generation and supply, lack of good roads, water supply, hospitals, competent educational training, political instability which had necessitated the emergence of extremist militant groups, kidnapping, robbery gangs and most importantly, government policies which are inconsistently implemented.

According to (Wheelen and Hunger, 2010), an analysis of the environment which includes the natural, societal and task environments has the propensity of making small business such as services, retailing, construction, financing, insurance, transportation and manufacturing to be successful in much of the industries group. Achieving this will however depend on the creative abilities of an entrepreneur who has had formal education on how to exploit the environmental opportunities and remain sustained in business. With the backwardness of numerous individuals with naturally given potentials to involve in entrepreneurship, but fall short of requisite entrepreneurial knowledge and many other confronting challenges in existence, entrepreneurship venture has not assumed its full recognition in Rivers State.

Consequent upon this introduction, this paper is basically involved in an indent review and an understanding of the distinctive entrepreneurial competencies for entrepreneur in Rivers State to enable them 
gain competitive advantage in a populated and competitive environment. It also establishes the imperative of entrepreneurial competencies as enabling features to determining the environmental opportunities and threats derivable through industry and market analysis. It also examines the extant challenges and the competitive intelligence required to gain competitive advantage.

\subsection{Objectives Of The Study}

Distinctive entrepreneurial competencies play innumerable vital roles in accomplishing competitive advantage in any competitive environment. Within the context of the above assertion, the aims of this research was to investigate the following specific objectives.

1. To examine the distinction entrepreneurial competencies required by entrepreneur in River State as panacea for competitive advantage over rivalries

2. To examine the predominantly entrepreneurial challenges that has instilled fear of failure among entrepreneurs in Rivers State.

3. To examine how entrepreneurial commitment represents a key component in an individual ability to predict the future.

4. To investigate the imperative of knowledge of entrepreneurial competitive intelligence on entrepreneurs wealth creation.

\section{Theoretical Framework}

Entrepreneurial competencies facilitate the creation of new products, ideas and innovation (Dittis and Prough, 1987; Lygun and Owen, 1999). This therefore means that every entrepreneur by virtue of his or her involvement must build the spirit to make changes in products or services, do new things and add value to existing things in order to be able to run a successful business. From research findings, there are thirteen competencies grouped differently and are essentially needed by every entrepreneur (Michelmore and Rowley, 2010). For the purpose of this paper, four of these competencies will be discussed extensively as constituting the distinctive competencies. These had been used by many authors that had written about entrepreneurial competencies. These include:

1. Pro-activeness

2. Risk taking

3. Innovativeness

4. Creativity

\subsection{Pro-activeness}

Pro-activeness according to Jun and Deschoolmeester, (2003), is the mental skill to take action unilaterally when the need arises both in conducive and turbulent situations. They maintain that this can be justified by the influence of external trends which affect products and services, markets, organizations all over the world. Changes in external environment would influence changes in the demand for industrial products and services as well as consumer products and services Fred R. David, (2010). As a starting point for competition, entrepreneurs must as a matter of concern engage their proactive competence to fight against expected external trends that have the capability of affecting consumer demand for goods and services either positively or negatively. In other words, the proactive competence of an entrepreneur is mostly needed more in as much as situation demands it.

\subsection{Risk Taking}

Risk taking according to Priceto, (2010) involves the decision to allocate resources to venture with a high expectation of failure. Entrepreneurship assumes varying categories of risks which includes those they could very well understand and manage Thompson, (1999). Again Jun and Deschoomeester (2003) Cunningham and Lischeron (1991), states that the entrepreneur prefer taking moderate risk in situations where they have an amount of control and requisite skills to achieve profit. In other words, according to them, entrepreneurs are not just risk takers because they want to take risk, but because the situation demands it. This however means that entrepreneurs look at themselves to know if they can handle the risks or not and also engage their mental judgment in calculating their abilities to take risks. Risk taking competence of entrepreneur impact positively on performance and are taken only when situations require it. For the concerned purpose of profit achievement and growth, entrepreneur should be involved in the creation of new business with appropriate consideration of the risk and uncertainly inherent within the business environment. This will certainly enable the identification of the significant environmental opportunities and the subsequent priority to making available the required resources to exploit the opportunities. As a consequence, the following leading questions have been suggested by Zimmerer and Scarborough (2003) before engagement.

1. What dangers could befall me if my business fails at start. 
2. Is it possible to be faced with these dangers?

3. What are the options available to reduce the dangers ahead?

4. If my business eventually fails, what plans will I depend upon?

\subsection{Innovativeness}

According to Zimmerer and Scarborough (2013), innovation is one of the entrepreneurial secrets and perhaps not a secret for creating value in the market place. They believe that in other words, innovation is the ability to apply creative solutions to problems and opportunities to enhance or enrich people's lives. In the work of Thompson, (2004), as found in Bolton and Thompson, (2000), an entrepreneur is described as an individual that has creative and innovative capabilities to build something adjudged as having value within a favorable entrepreneurial environment. According to them, this suggests that entrepreneurs must identify several opportunities which become the threshold for innovative capabilities. Makhbul and Hasun, (2011), and Mitchelmove and Rowley (2010), consider notifying and exploiting opportunities as competencies of entrepreneurs.

According to Sullivan, (2009), the term innovation has continued to be a very important topic worthy of study across number of disciplines. But it is good of note strongly that the term is interchangeably used with such terms as change, design, and creativity. It comes into focus in the area of products, process or services in any given organization. In other words, it involves a process that transforms ideas into outputs capable of increasing values adjudged by customers in relation to the products, process and services.

Sullevan, (2009), sees innovation as a process of introducing unique changes to either products or services adjudged by consumers as having added value, thereby giving the organization a colossal recognition in the industry. The objective lies on its ability to make available the necessary financial and skills resources required to exploit the opportunities, develop the opportunity and make others benefit from the innovation. Once an entrepreneur has identified possible opportunities and set up an organization, the whole idea becomes obsessed on its sustainability which can only be realized through organizational innovation. The resultant effect of this is that it will enable more customers to adapt to the products. Not only can innovation introduce new products and services that enrich the lives of individuals both nationally and international, it can also contribute significantly to economic growth, Sullivan (2009).

\subsection{Creativity}

Creativity as the word sounds is a critical entrepreneur's required competence, because an entrepreneur's clear preference for independence is associated with distinctive creativity, (Planmen and Salopaju, 2011). Creativity is the mental skill to develop new ideas and to explore new way of looking at problems and opportunities Thomas W. Zimmerer et al, (2013). In the face of competition coupled with a globe that is ever changing faster than expected, creativity becomes vital to an entrepreneur's success and survival. For an entrepreneur, thinking creatively is a necessarily required skill which must be developed and always applied. This creative skill obviously lies at the heart of an entrepreneur's ability as a necessary means to compete successfully with rivals. Entrepreneurs can create effective competitive advantages over rivals by being more creative and regarding it as a key to innovation (Rosenfeld and Servo, 1991).

\subsection{Entrepreneurial Challenges in Rivers State}

Considering the spate of income disparity and the current hard pressed economic situation around the globe, and Rivers State in particular, 95\% of individuals in Rivers State have the willingness and enthusiasm to start up their own businesses, but have the fear of not being successful because of some inherent challenges that are obvious. The dwindling electricity challenges according to Mike Duru (2011), indicates that poor infrastructural challenges also affect a large percentage of the population. The supply of electricity now has degenerated more in the rural areas, and even when available, the supply is often disgusting and unreliable. Because of non-availability of regular power supply, $98 \%$ of Rivers-State entrepreneurs use generator set as substitutes which can only be powered by premium motor spirit (PMS). Despite numerous oil wells naturally found in Rivers-State, crude is being exported for refining and imported back to the state. This has resulted to diversion of refined crude to unofficially approved designated ports, hence making the refined crude to be scarce with its unprecedented skyrocketed price per liter such that it becomes difficult for willing entrepreneurs to afford. Education is a fundamental prerequisite for a nation's development. This has lost its fame in Rivers State as a result of corruption. Emphasis are no longer on grooming human knowledge, thus, have negated the full teaching of fundamentals of entrepreneurship, more especially, the analysis of the industry and environmental factors for a sustainable business venture. Virtually all roads leading to the suburbs are in deplorable conditions and are not given full attention by the state government. The scenario has created a drastic depletion of concern for entrepreneurial venture. Modern and well equipped health facilities are devastating because of the corrupt minds of the political elites who are non-proactive in thoughts for the generality of the population, but are more 
obsessed with individual wealth creation. The aforementioned challenges have created unprecedented drawbacks among entrepreneurs in Rivers State. According to Zimerer and Scarborough (2013) these drawbacks are expressed in:

1 Income Uncertainty: Every entrepreneur believes that he or she is guaranteed of making enough money to survive. It hence suffices to say that entrepreneurs hardly earn enough income from his or her business to justify the reason for being an entrepreneur (Thomas and Scarborough, 2013).

2. Loss of Entire Investment: There is the contentious belief amongst entrepreneurs in Rivers State of losing the entire business because the rate of business failure is high. According to the findings of Thomas and Scarborough, (2013), and comparing with this research findings, 64\% of new businesses have shut down and over $84 \%$ will fold in four years to come. Thus, entrepreneurs in Rivers State are obsessed with the fear that in as much as their businesses will operate in an environment of risk and uncertainty, and surrounded by rapid challenges, have hence concluded that failure is likely to be experienced. It should however be noted that failure can be expected, but be known as a creative process (Thomas and Scarborough (2013).

\subsection{Panacea for Entrepreneurs' Challenges}

For a considerable realization of the actual Rivers State government intensions which brought into fore the skills acquisition program, poverty alleviation program, entrepreneurial development program, it therefore becomes imperative for the state government to introduce an entrepreneurial orientation as a priority for the development of entrepreneurs. This should involve skilful educational training on the need to accept failure as part of an entrepreneurial creative process which can turn into success by commitment. Again, every entrepreneurial policy of the government must not be introduced to compensate political godfathers and loyalists. It sincerely would mean that Rivers State government must have to provide creative education to teach entrepreneurship, irrespective of level of education. The provision of adequate infrastructure such as generation of electricity, good roads, water supply, hospitals, must be optimized with priority attention to necessitate high level of confidence on entrepreneurs for success. Good roads must also be constructed to ease faster and conducive movement. Where potholes are identified, the State Emergency Management Agency (SEMA) must be empowered to adequately involve in repairs that may degenerate into halting flow of traffic. This has the tendency of allowing entrepreneurial activities outside the urban areas. Construction of hospitals with specialists employed and well equipped with facilities for adequate medical attention should also be put in place. This will assist strongly in saving lives of entrepreneurs whose activities will impact positively on the lives of Rivers people and beyond.

\subsection{Entrepreneurial Commitment/Dedication}

Entrepreneurial dedication defines the aggregate amount of physical and mental activities that could be expended by an entrepreneur willing to be fully dedicated Martin Zwilling (2011). In the work of Gartner (1989), entrepreneurial commitment represents a key component in an individual ability to predict entrepreneurial outcome, and also a crucial component to any cognitive view of an entrepreneur. Martin Zwilling (2011) maintains that there is no middle road to commitment, and if you are not ready to fully commit to all rigorous of a startup, you are better off sticking with your current role. This assertion clearly demonstrates that an entrepreneur's commitment is a threshold for success in an environment that involves stern competition. Thus, the commitment cuts across controllable environment to exploit strengths and uncontrollable environments to exploit opportunities to take advantage of the threats. The following seven characteristics of a committed entrepreneur are identified by Martin Zwilling (2011).

1. Exhibit Leadership and Responsibility: In this commitment role, entrepreneurs are expected not only to make decisions, but to make decisions based on critical analysis of available alternative courses of action that will result in the achievement of best results.

2. Ambitious and Confident: Entrepreneurs who are dedicated are expected to be very ambitious and have utmost confidence in their abilities, have many ideas, some of which may confidently work more perfectly than others. However, for those which may not work very well to achieve success, can then be seen as guide for learning to exploit the opportunities.

3. Expect Less Positive Feedback: For an entrepreneur to become fully committed, he or she must be ready to accept responsibility for all things without expecting any form of feedback from anybody.

4. Social Life Must not have Unprecedented Priority: There is no doubt that social relationship is absolutely important as a motivator from the study of Elton Mayo and his associates conducted near Chicago at Western Electric's Hawthorne plant between 1927-32, but as an entrepreneur, it should not be considered more important such that it overrides the performance expectations of an entrepreneur.

5. Comfortable with Unprecedented Working Hours: Committed entrepreneur must never be confined with specific work schedules, but he or she needs to be flexible and assume that there will be long and unusual working hours. 
6. Vacation Hours Must be Interrupted: Consequent upon the competitive environment and to sustain the advantages in the industry, committed entrepreneur is expected back home with his or her work requirement most often.

7. Retirement Thought Absurd: A committed entrepreneur need not even think of retirement as many people involved in startups do. This distinguishes entrepreneurs who are risk takers from those who are optimistic to fail because of fear.

\subsection{Entrepreneur's Competitive Intelligence}

Entrepreneurs require being engrossed with competitive intelligence by dint of their desire to be independent and achieve growth in a competitive industry. Competitive intelligence involves the use of public sources to develop data on competition, competitors and the market environment and transform the data by analysis into intelligence McGonagel and Vella, (2002). They maintain that competitive intelligence means all the relevant information that could be gathered by a lawful and ethical means.

\subsection{Types Of Competitive Intelligence}

There are different significant competitive intelligence that entrepreneurs must be abreast of to gain market advantage over rivalries. These are as follows according to (McGonagel andVella, 2012):

1. Strategic Intelligence: This competitive intelligence acts as a supporting strategy needed by entrepreneurs to furnish them with information bordering on high-level intelligence knowledge concerning the state of competitive economic and political environment in which a firm operates currently and will operate in future period of time.

2. Competitor Intelligence: This competitive Strategy mainly focuses on current capabilities, activities, proposal and intentions of competitors. Furthermore, it helps to answer questions bordering on.

(1) Knowledge of competitors.

(2) Knowledge of potential customers.

(3) How do potential customers compare themselves with others?

(4) Knowledge of target market of competitors.

(5) Knowledge of the future strategic move.

3. Market Intelligence: This intelligence enables entrepreneurs to be involved in identifying activities in the market place such as market research, sales force, pricing, promotion, payment, financing and market planning. The will enable entrepreneurs to provide data on the success and failure of rival firms in the industry.

4. Technical Intelligence: This competency permits the entrepreneur to find out technology used by competitors in order to take advantage of the inevitable technical and scientific changes in the industry, and be able to respond to any problems associated with the changes.

\subsection{Importance of Competition To An Entrepreneur's Wealth Creation}

Competition involves rivalries between firms striving to gain sales and market Profit. An entrepreneur according to Thomas and Scarborough (2003) is one who identifies a different business despite the risks and uncertainties in order to make profit and grow. He explores opportunities and gathers the necessary resources for achievement. Growth therefore can only be realistic when an entrepreneur understands the competitive strategies that could be identified through the entrepreneurial competencies.

Competition is inevitable in the operation of market and as a result, encourages innovation, productivity and growth which eventually create wealth. While markets work fairly well sometimes, competition is affected by ineffective government laws and policies. In as much as effective competition influences productivity, competitive policy should be an essential component of growth strategy. Aggressive competition has the tendency of reducing corruption chances, and thus, allows entrepreneurs to flourish. The magnitude of competition influences the competitive strength of an entrepreneur, both in the export, import and home markets.

\subsection{Industry And Market Analysis}

The analysis of the industry and targeted market segment is most important for an entrepreneur as a starting point considering the inherent external environmental factors that could pose as threats and possible opportunities. The comprehensive analysis of the industry hence, transcends into making a choice of which one is most attractive.

The choice also requires would be entrepreneurs to access not only industry trend, but also their own skills to meeting the demands in the industry. In other words, the choice of industry to compete in with respect to emphasis on distinctive competencies becomes the entrepreneur's strategy and how the strategy will be implemented. 
However, the major underlying concern according to Thomas and Scarborough (2003) is the determination of:

1. How attractive an industry is for a startup business?

2. To identify virgin areas a small business can occupy profitably. They maintain that the first step in assessing an industry's attractiveness is examining it from "Macro" level which must involve giving answers to the following questions:

1. What is the size the industry?

2. What is the speed of growth?

3. What is the industry's rate of return?

A strong and complete analysis of these questions could give an insight to the entrepreneur on whether his products or services can call for higher demand to remain competitive. It is worthy to note that most small businesses such as service, retailing, construction, financial and insurance wholesaling, transportation and manufacturing are found in major successful industry group. Hence, an analysis of the industry by all entrepreneurs according to Wheelen and Hunger (2010) would include the natural, societal, and task environments.

The analysis of the market therefore can further be achieved using the five forces model developed by Michael Porter of the Harvard business school, an authority in competitive strategy. He contends that a corporation is most concerned with the intensity of competition within its industry, and that the level of intensity is determined by basic competitive forces which in turn determines the profit level in the industry

\section{Methodology}

The study adopted the quasi-experimental research design and review of related literature for gathering data. The choice of quasi-experimental research design was subject to the fact that the entrepreneurs who are in their private businesses are exposed to complex relationships which are not subject to manipulation. Thus, a field study or a sample survey method was extensively used in gathering data. The population of the study consisted of entrepreneurs in servicing, transportation, manufacturing, insurance and retailing totaling 100 entrepreneurs under the umbrella body of small and medium enterprises in Rivers State. The sample size drawn from the entire population was 80 entrepreneurs at $95 \%(0.05)$ confidence level indicating the chance that the sample is distributed in the same way as the population to which the findings of the study were applicable. The questionnaire was divided into three parts to solicit information on:

1. The biological characteristics of the respondents

2. Distinctive entrepreneurial competencies and

3. Entrepreneurial wealth creation through industry analysis.

The variables of the study were measured with 6 item questions on a 5-point Likert Scale as $1=$ strongly agreed to $5=$ strongly disagreed. The research instrument was validated with use of opinions of professionals in the field of study. The generalized data for the research analysis were proved to be consistent and accurate with the use of Cronbach Alpha Test at 0.79 which indicated high and strong reliability.

\section{Results And Discussions}

A sample size of 80 entrepreneurs were drawn from a population of 100 using Bowley's population proportion distribution technique applied on each group of the entrepreneurs in the small enterprises in Rivers State. The major sources of data generated for the study were through the administration of questionnaire and the use of personal interview. To prorate the questionnaire distribution to entrepreneurs in the subjectively chosen five small-enterprises, the Bowley's population proportion distribution technique was employed which totaled 67 number of questionnaire distributed and represented $83.75 \%$ of the total questionnaire. Out of these, 54 questionnaires were fully returned which represented $81 \%$ and 13 were not returned which represented $19 \%$. The data generated were used for the descriptive analysis of the study. However, the secondary data were used to provide the theoretical background as in the review of literature. The questionnaire applied the 5 point Likert scale ranging from $1=$ strongly agreed

To $5=$ strongly disagree

\section{Presentation of Table}

\subsection{Determination Of Sample Size For The Study}

\begin{tabular}{|l|l|l|l|l|}
\hline S/No & Name Of Organization & Population Size & Sample Size Drawn & \% Of Sample \\
\hline 1. & Servicing & 10 & 8 & 10 \\
\hline 2. & Manufacturing & 25 & 20 & 25 \\
\hline 3. & Insurance & 20 & 16 & 20 \\
\hline 4. & Transportation & 15 & 12 & 15 \\
\hline 5. & Retailing & 30 & 24 & 30 \\
\hline & Total & $\mathbf{1 0 0}$ & $\mathbf{8 0}$ & $\mathbf{1 0 0 \%}$ \\
\hline
\end{tabular}

Source: Researcher's field survey, 2016 
Table 4.1 above showed researcher's subjective choice of five small enterprises in Rivers State. The judgmental sampling technique reflected on the population size. The sample size drawn was calculated using Bowley's population proportion and distribution technique and expressed in percentage.

Table 4.1.1: Questionnaire Distribution

\begin{tabular}{|c|c|c|c|c|c|c|}
\hline S/No & Name Of Organization & Population Size & \% Of Sample & No. Of Questionnaire & No. Returned & $\begin{array}{l}\text { No. Not } \\
\text { Returned }\end{array}$ \\
\hline 1. & Servicing & 10 & 8 & 7 & 5 & 2 \\
\hline 2. & Manufacturing & 25 & 20 & 17 & 14 & 3 \\
\hline 3. & Insurance & 20 & 16 & 13 & 11 & 2 \\
\hline 4. & Transportation & 15 & 12 & 10 & 8 & 2 \\
\hline \multirow[t]{2}{*}{5.} & Retailing & 30 & 24 & 20 & 16 & 4 \\
\hline & Total & 100 & 80 & 67 & 54 & 13 \\
\hline
\end{tabular}

Source: Researcher's field survey, 2016

The table above indicated total number of questionnaire prorated using Bowley's population proportion distribution technique and distributed to the samples drawn from the five subjectively chosen small enterprises and the entrepreneurs involved in Rivers State.

Table 4.1.2 Biographical Characteristics

\begin{tabular}{|l|l|l|l|}
\hline Description & 8 years and Above & Frequency & \% \\
\hline Years in operation & Male & 33 & 61.15 \\
& Female & 21 & 38.88 \\
\hline Qualification & Bachelors & 40 & 74.07 \\
& Masters & 14 & 25.92 \\
\hline Marital status & Married & 35 & 64.81 \\
& Single & 19 & 35.18 \\
\hline Gender & Male & 35 & 64.81 \\
& Female & 19 & 35.18 \\
\hline Age & Male 20 -45 & 33 & 61.15 \\
& Female 20 - 36 & 21 & 38.88 \\
\hline
\end{tabular}

The above table represented the frequency of the biographical characteristics of the entrepreneurs studied and expressed in percentages

\section{Operational Measures of the Objectives of the Study}

Table 4.1.3: The Relevance Of Distinctive entrepreneurial Competencies

\begin{tabular}{|c|c|c|c|c|c|c|}
\hline Question & Organization & $\mathbf{S a}$ & $\mathbf{A}$ & $\mathbf{D}$ & Sda & Und \\
\hline I have total entrepreneurial ability to successfully perform a job. & Servicing & 0 & 0 & 3 & 2 & 0 \\
\hline $\begin{array}{l}\text { Entrepreneurial competencies facilitated the creation of new } \\
\text { product idea and innovation }\end{array}$ & Manufacturing & 1 & 2 & 4 & 6 & 1 \\
\hline $\begin{array}{l}\text { My proactive competency has translated changes in the external } \\
\text { forces into changes in consumer demand. }\end{array}$ & Insurance & 1 & 3 & 4 & 2 & 1 \\
\hline $\begin{array}{l}\text { I have degree of control and skill in realizing profit in any risk I } \\
\text { take }\end{array}$ & Transportation & 1 & 1 & 1 & 4 & 1 \\
\hline $\begin{array}{l}\text { My innovative competence enables me to introduce something } \\
\text { new that adds value }\end{array}$ & Retailing & 2 & 3 & 6 & 3 & 2 \\
\hline \multicolumn{7}{|l|}{ My creative competence enables me think new things } \\
\hline & Total & 5 & 9 & 18 & 17 & 5 \\
\hline
\end{tabular}

To measure the distinctive entrepreneurial competencies operationally, the respondents were asked to indicate their respective opinions on questions that were asked. 35 out of 54 respondents cumulatively indicated disagree and strongly disagree while 14 indicated strongly agree and agree respectively and only 5 showed undecided. This implies that a greater number of the respondents are unaware of the importance of distinctive competencies.

Table 4.1.4 Entrepreneurial Challenges

\begin{tabular}{|c|c|c|c|c|c|c|}
\hline Question & Organization & Sa & $\mathbf{A}$ & Da & Sda & Und \\
\hline That: irregular power supply influences my fear of losing & Servicing & 0 & 0 & 3 & 2 & 0 \\
\hline I do not invest in rural areas because of bad roads & Manufacturing & 1 & 2 & 4 & 6 & 1 \\
\hline No priority attention to fully equip government owned hospitals & Insurance & 1 & 3 & 4 & 2 & 1 \\
\hline Government policies on kidnappers are not implemented & Transportation & 1 & 1 & 1 & 4 & 1 \\
\hline Corruption rate is on the high level without control & Retailing & 2 & 3 & 6 & 3 & 2 \\
\hline \multicolumn{7}{|l|}{ The high price per litre of fuel impacts negatively on my business } \\
\hline & Total & 5 & 9 & 18 & 17 & 5 \\
\hline
\end{tabular}


The above table showed cumulative responses of respondents on questions asked concerning entrepreneurial challenges. The cumulative effects of their responses showed that 35 respondents are strongly affected by different entrepreneur's challenges by indicating DA and SDA respectively 5 respondents and 9 indicated SA and A on the questions concerning challenges, while only 5 were undecided. The implication is that lacks of entrepreneurial venture in Rivers State are attributed to inherent challenges existing within the societal environment.

Table 4.1.5 Entrepreneurial Competitive Intelligence

\begin{tabular}{|c|c|c|c|c|c|c|}
\hline Question & Organization & Sa & $\mathbf{A}$ & Da & Sda & Und \\
\hline $\begin{array}{l}\text { My knowledge of competitive intelligence influences growth and } \\
\text { profit }\end{array}$ & Servicing & 1 & 0 & 3 & 1 & - \\
\hline I have public sources to develop data on competition & Manufacturing & 1 & 2 & 2 & 8 & 1 \\
\hline $\begin{array}{l}\text { I know the competitive economic, political environment in which } \\
\text { we operate now }\end{array}$ & Insurance & 5 & 3 & 1 & 1 & 1 \\
\hline $\begin{array}{l}\text { Competitive intelligence enable me to know my competitor's } \\
\text { capabilities }\end{array}$ & Transportation & 1 & 2 & 3 & 2 & \\
\hline $\begin{array}{l}\text { I do market planning by providing data on the success and failure } \\
\text { of my rivals }\end{array}$ & Retailing & 2 & 5 & 6 & 2 & 1 \\
\hline \multicolumn{7}{|l|}{$\begin{array}{l}\text { I know my competitor's current manufacturing methods through } \\
\text { technical intelligence }\end{array}$} \\
\hline & Total & 10 & 12 & 15 & 14 & 3 \\
\hline
\end{tabular}

From the table, the cumulative effect of the respondents if divided into SA/A and DA/SDA indicated DA/SDA as outnumbered SA/A and only 3 indicated no option. This outnumbering is hence explained by inadequate knowledge of the values of competitive intelligence by entrepreneurs in Rivers State as a strategy to outwit rival firms in an industry.

Table 4.1.6: Effect Of Industry Analysis

\begin{tabular}{|c|c|c|c|c|c|c|c|}
\hline Question & Organization & Sa & $\mathbf{A}$ & Da & Sda & Und & \\
\hline My analysis involved identifying possible niches to be profitable & Servicing & 0 & 1 & & 2 & & \\
\hline My new business is attractive in the industry & Manufacturing & 2 & 1 & 4 & 2 & & \\
\hline I know the elements that directly affect my business & Insurance & 1 & 1 & 4 & 5 & & \\
\hline I know that the number of competitors is large & Transportation & - & - & 3 & 5 & & \\
\hline I know much of my market & Retailing & 1 & 2 & 8 & 4 & 1 & \\
\hline \multirow[t]{2}{*}{$\begin{array}{l}\text { I know of the natural, societal, and task environment's effects on } \\
\text { business }\end{array}$} & & 1 & & & & & \\
\hline & Total & 4 & 5 & 19 & 25 & 1 & 54 \\
\hline
\end{tabular}

From the table, the cumulative effects of the respondent proved that 44 respondents indicated DA and SDA opinions, leaving only 4 and 5 respondents who indicated SA and A, and 2 persons undecided on questions bordering on industry analysis before delving into startup venture. This shows a clear indication of not being abreast of the basic teachings of the entrepreneurial concepts for a sustainable venture startup.

\section{Recommendations}

From the results of the research study, it is obviously imperative to conclude that knowledge of entrepreneurial distinctive competencies is very imperative for entrepreneurs in Rivers State. This underpins the reason for taking initiative whenever circumstances demand it because external trends can significantly affect market demands. It is also important to note that risk taking impacts positively on performance and that moderate risk taking enable entrepreneurs to have an amount of control and requisite skills in achieving profit. The acquisition of innovative competence enables entrepreneur to create something new that will add value to consumers and thus keep him or her more successful in the industry. As a consequence of the competitive nature of the business environment, creativity competence becomes much more imperative because of the desire to develop new mental abilities and new method of looking at problems.

In addition, the provision of basic infrastructure such as electricity, good roads, portable water, hospitals, schools play unprecedented roles in the achievement of entrepreneurial venture. Good and effective government policies and their timely and adequate implementation necessitate wealth creation and create confidence in the minds of entrepreneurs that failure can turn to success through hard work. However, the possibility of business failure can also not be ruled out completely. Future events and trends cannot be controlled by humans. This has the tendency of negating the pro-activeness, risk taking, creative and innovative competences of entrepreneurs for competitive advantage over rivalries. It is then recommended that entrepreneurs in Rivers State needs to take advantage of all the government entrepreneurial polices and delve into startup venture. 
This fundamentally has the capability of reducing unemployment rate, social vices such as kidnapping, militant groups, armed robbery and street roaming. Further studies should be done on other competencies, to see how they complement with the four distinctive competencies studied for successful entrepreneurs

\section{References}

[1]. Anthanassiou, N; McNett, J.; and Harvey, C. (2003). Critical thinking in management classroom: Bloom's Taxonomy as a learning tool. Journal of Management education, 27 (5), 533-55.

[2]. AnupamaBains (2013). Supervisor, Punjabi University, Patiala (Pb) India.

[3]. B. ChimaOnuoha. (2012). Business and Entrepreneurial Environments. A Nigerian Perspective.

[4]. B. ChimaOnuoha. (2008). Analysis of factors responsible for SME's and Entrepreneurial failure in Nigeria. African Journal of entrepreneurship: Vol. 1, No. 3, Dec, 2008.

[5]. B. ChimaOnuoha. (2007). Entrepreneurial Development in Nigeria.An Integrated Perspective.

[6]. Berlew, D. (1975). The nature of entrepreneurs

[7]. Borges, A. (2001). At risk student and virtual enterprise: Tourism and Hospitality Simulations in Applied and Academic learning, Eric Database number; ED469902.

[8]. Cherwitz, R. A; and Sullivan, C. (2002). Intellectual entrepreneurship: A vision for graduate education.

[9]. HardeepKaur, (2013). Research scholar, Puryabi University Patiala (Pb) India.

[10]. Herrmann, N. (1995). The creative brain. Kingsport, TN: Quebcor Printing Book Group.

[11]. Homer-Dixon, T. (2000). The ingenuity gap: facing the economic, environmental and other challenges of an increasingly complex and unpredictable future. New York, NY: Knopf.

[12]. Ibrahim, A. B; and Soufani, K. (2002). Entrepreneurship Education and Training in Canada. A critical assessment.Education and Training.

[13]. Kanungo, R; and Misra, S. (1992). Managerial resourcefulness: A Reconceptualization of Managerial Skills. Human relations 45(12), 1311-1333.

[14]. Michael H. Morris, (2014). Annals of entrepreneurship education and pedagogy.

[15]. Martinadale, C. (1999). Biological bases of creativity. In R. J. Sternberg (ed), Handbook of creativity. Cambridge, UK: Cambridge University Press.

[16]. Martin Zwilling, (2011). http://www.businessinsider.com/sevenofa committed entrepreneur 2011-1.

[17]. Minniti, M. (2004).Entrepreneurial alertness and asymmetric information in a spin-glass model. Journal of Business venture, $19,637-58$

[18]. MHchelmore, S. and Rowley, J. (2010). Entrepreneurial competencies: A literature review and development agenda. International Journal of entrepreneurship education.

[19]. MHchell, R. K. (2011). Increasing returns and the domain of entrepreneurship research.Entrepreneurship theory and practice, July, 35-6,615-29.

[20]. Morris, M. H., Webb, J. W., Fu, J. and Singhal, S. (2013). A competency based perspective on entrepreneurship education: conceptual and empirical insights. Journal of Small Business Management.

[21]. Pickett, L. (1998). Competencies and Managerial effectiveness: Putting competencies to work. Public personnel management 27(1),103-115.

[22]. Rajeev, Roy. (2013). Entrepreneurship $2^{\text {nd }}$ ed. Exford University Press.

[23]. Rasmussen, E., Mosey, S., and Wright, M. (2011). The evolution of entrepreneurial competencies.A longitudinal study of University Spin-off Venture emergence. Journal of Management Studies, 48(6), 1314-45.

[24]. Thomas W. Zimmerer, and Norman, M. Searborough (2013).Essentials of entrepreneurship and small business management, $5^{\text {th }}$ ed. Phi Learning Private Hd. Delhi.

[25]. Thomas L. Wheelen, and J. David Hunger (2010). Strategic Management and Business Policy.Achieving sustainability.12 ${ }^{\text {th }}$ ed. Prentice Hall.

[26]. Volkmann, C. (2004). Entrepreneurship studies: An ascending academic discipline in the $21^{\text {st }}$ century. Higher education in Europe, $29(2), 177-85$ 